Рекомендована д. фрармац. наук, проф. Т. Г. Калинюком та кан. фрармац. наук, доц. Н. І. Гудзь

UDK $637.146 .2: 615.32$

\title{
DEVELOPMENT OF THE LABORATORY TECHNOLOGY OF THE FUNCTIONAL FOOD KOUMISS
}

\author{
co. S. Kalyuzhna \\ National University of Pharmacy, Kharkiv
}

\begin{abstract}
Summary: based on the results of the experimental studies and the conducted analysis the composition of koumiss (namely pasteurized skimmed cow milk, powdered skimmed milk, honey, dry (alcohol flora) and ready biokefir (lactic acid flora), drinking water) has been selected, and the laboratory technology for its preparation have been developed. Koumiss is a functional food product. The rational method of fermentation (namely separate fermentation), which is the main stage in the process of koumiss preparation, and the amount of the fermentation starter (20\%), the proportion of lactic acid and yeast flora in the starter (2:1) have been chosen.
\end{abstract}

Key words: koumiss, functional food products, laboratory technology.

Introduction. The works on the development and research of functional foods and nutraceuticals are rapidly expanding throughout the world [1]. According to the definition of the European Commission Concerted Action on Functional Food Science in Europe (FUFOSE) functional food is a food that beneficially affects one or more target functions in the body beyond adequate nutritional effects in a way that is relevant to either an improved state of health and well-being and/or reduction of risk of disease [2]. It is consumed as part of a normal food pattern. Fermented milk products (FMP) deserve special attention among the great number of functional foods [3].

In most countries of the world, particularly in Ukraine, people more often use cow milk, at least - milk of goat, sheep, mare and more rarely - milk of camel, bull, deer in their diet [4]. Based on various kinds of milk and beneficial microorganisms different types of FMP are obtained by fermentation.

For our region traditional FMP are kefir, yogurt, ryazhenka, sour cream, etc. [5]. The non-traditional FMP for our region on the basis of the traditional cow milk, as well as other types of raw milk have appeared due to the relevance of a healthy diet at the market.

In the context of this topic it should be also noted the people's desire to consume the ecologically safe products free of impurities and additives. Therefore, in recent years recipes which can help people to prepare healthy FMP at home have become very popular in Ukraine [6-8].

The new products for our market are ayran, tan, koumiss, matsun and etc. Koumiss, which is a very popular FMP for the people of Mongolia, Kazakhstan, Kyrgyzstan, and some regions of Russia and Bulgaria, has been chosen as the object of this work. This beverage is made of mare milk by a joint natural fermentation of lactic acid bacteria and yeast (lactose is fermented to lactic acid and alcohol) [4, 9].
It is known that in some countries koumiss is used as a medicine to treat some diseases of the cardiovascular, digestive, and neurological systems, and to cure infections such as tuberculosis. Treatment effects of koumiss are due to the composition of mare milk, and some bioactive components, mainly antimicrobial agents, may be formed through fermentation of lactic acid bacteria and yeasts [4].

The aim of this work was to develop the technology for laboratory preparing koumiss, which is functional food product that is non-traditional for our region FMP.

Research methods. To assess efficiency of the process of fermentation, the number of yeast cells and titratable acidity were determined. The total number of yeast cells was counted by the usual method using conventional light microscopy with the Goryaev counting chamber. The titratable acidity was measured by the titrimetric method or by reacting the acids present with sodium hydroxide $(0.100 \mathrm{M} \mathrm{NaOH}$ solution) to a chosen end point, close to neutrality, as indicated by an acid sensitive colour indicator (phenolphthalein) [10].

The study of the qualitative composition (the presence of lactic acid bacteria and yeast) of products was performed by the method of the Gram stain [11].

The study of the quantitative composition (the number of lactic acid bacteria and yeast cells) of products was performed by the Koch's pour-plate method [12]. This method is in making serial dilutions of the sample $(1: 10,1: 100,1: 1000$, etc.) in sterile water and cultivation on the nutrient agar (MRS agar - for lactic acid bacteria and Sabouraud dextrose agar - for yeast) in a Petri dish that is sealed and incubated. To be effective, dilution of the sample was arranged so that on average 30-300 colonies of the microorganisms grew (for yeast - up to 100). After appropriate incubation (for 24-48 $\mathrm{h}$ at the temperature of $37^{\circ} \mathrm{C}$ for lactic acid bacteria and at $27^{\circ} \mathrm{C}$ for yeast) the dishes were examined for the presence

ISSN 2312-0967. Pharmaceutical review. 2015. № 2 
Фармацевтична технологія, біофармація, гомеопатія Pharmaceutical technology, biopharmacy, homeopathy

of colonies grown on the medium. The unit of measurement is CFU/ml (colony forming units per milliliter). Calculation of this is a multiple of the counted number of colonies multiplied by the dilution used.

Results and Discussion. The first stage was the selection of ingredients for the preparation of koumiss in the laboratory conditions from the raw material available for our region. Koumiss is usually made of mare milk, but the industrial horse breeding in our country is underdeveloped [13], so this kind of the milk raw material is not economically and technologically feasible.

Mare milk contains the lower content of protein and fat and the higher content of lactose than cow. It is necessary to modify cow milk to make it suitable for preparation of koumiss because of the difference in composition between mare and cow milk because of the difference in composition between mare and cow milk, $[4,9]$.

In industrial conditions for production of koumiss the skimmed cow milk is used; it is pasteurized, i.e. subjected to heat treatment at a temperature of $80-82{ }^{\circ} \mathrm{C}$ for $5 \mathrm{~min}$, and whey proteins precipitated in the form of suspension during pasteurization are dispersed by homogenization at a pressure of 12-14 MPa before fermentation [9, 13] Therefore, pasteurized skimmed cow milk was selected for koumiss preparation in the laboratory conditions.

Concentrates are added for the purpose of enrichment of cow milk with whey protein. Thus, powdered skimmed milk was chosen as a rather cheap and affordable ingredient.

As koumiss is the product of a complex lactic acid and alcoholic fermentation, dry baker's yeast containing species of Saccharomyces cerevisiae was chosen as the yeast microflora, and ready-made biokefir containing lactic streptococci - Streptococcus thermophilus and lactobacilli bacteria - Lactococcus lactis subsp. Lactis, Lactococcus lactis subsp. diacetylactis, Lactobacillus acidophilus, Lactobacillus delbrueckii subsp. Bulgaricus, Lactobacillus casei was used as the lactic acid flora.

Substrates (mainly lactose) that are rich in carbohydrates are necessary for the yeast growth [4]. For this purpose, producers, as a rule, add sugar in milk. We chose honey not only as a source of carbohydrates, but also as the substance, which additionally enriches the final product with healing properties.

The analysis conducted allows to choose such ingredients as the milk raw material - pasteurized skimmed cow milk and powdered skimmed milk, additional carbohydrate substrate - honey, microflora - dry baker's yeast (alcohol) and ready-made biokefir (lactic acid), drinking water to dissolve the ingredients.

The next step was to develop the koumiss preparation technology in the laboratory conditions. For this purpose it is necessary to determine such parameters as the proportion of lactic acid and the yeast flora in a fermentation starter, conditions (temperature, acidity, and time) of fermentation, the method of fermentation (separate or joint), the total amount of the fermentation starter and the raw material.

For active growth and reproduction of yeast the initial acidity should be about (48 \pm 2$)^{\circ} \mathrm{T}(\mathrm{pH}$ 5.4-5.2); it can be achieved by introducing a large amount of the fermentation starter. Since we used a noncommercial fermentation starter, and the so-called "domestic" (biokefir as a source of the lactic acid flora and baker's yeast as the alcohol flora), the best volume for the starter was determined experimentally. For this purpose we made products with different concentrations of the starter (from $10 \%$ to $30 \%$ of the total amount of the raw material); and also varied with the proportion of lactic acid and the yeast microflora (1:1, 2:1 and 1:2).

Industrially the fermentation is carried out at a temperature of $(29 \pm 1){ }^{\circ} \mathrm{C}$, which allows maintaining the symbiosis of lactic acid bacteria (the optimum growth temperature is $(35 \pm 2)^{\circ} \mathrm{C}$ ) and yeast (the optimum growth temperature is $(27 \pm 2){ }^{\circ} \mathrm{C}$ ) with constant agitation until reaching acidity (75-80) ${ }^{\circ} \mathrm{T}$ for $1-2 \mathrm{~h}$. In the laboratory conditions the achievement of this acidity during this time is doubtful.

Considering the conditions mentioned above the required parameters were determined by two methods: joint and separate fermentation. The efficiency of the process of fermentation was monitored by acidity and the number of yeast cells. The achievement of the final acidity $(75-80){ }^{\circ} \mathrm{T}$ is indicative about the end of the fermentation process.

In separate fermentation at first the lactic acid microflora (kefir) in different amounts and proportions (Table 1) was added in the milk raw material, this mixture was incubated at a temperature of $(37 \pm 1)^{\circ} \mathrm{C}$, being the optimal growth temperature for lactic acid bacteria, for 12 $\mathrm{h}$. Then the yeast prepared (diluted with warm water and kept for 10-15 $\mathrm{min}$ ) was added in the so-called "kislyak" obtained. This mixture was incubated at a temperature of $(27 \pm 2){ }^{\circ} \mathrm{C}$, being the optimum growth temperature for yeast. The gas bubble formation on the surface of the mixture observed in 1-2 $\mathrm{h}$ indicated the end of this stage of fermentation (it was also confirmed by the achievement of acidity $-78^{\circ} \mathrm{T}$ ). Acidity and the number of yeast cells were determined after the fermentation.

In joint fermentation lactic acid and the yeast flora prepared in different amounts and proportions (Table 2) were added together and fermented at $(29 \pm 1){ }^{\circ} \mathrm{C}$. Acidity and the number of yeast cells were determined every $6 \mathrm{~h}$.

It should be noted that the required value of titratable acidity $\left((75-80){ }^{\circ} \mathrm{T}\right)$ has been reached for separate fermentation in $13 \mathrm{~h}$ of the process and for joint fermentation in $70 \mathrm{~h}$.

As seen in Tables 1 and 2, such indicator of efficiency of fermentation as the number of yeast cells depends on the proportion of lactic acid and the yeast flora in the fermentation starter, and the indicator of titratable acidity - in a lower degree. The results of the studies for determining parameters and the method of fermentation

ISSN 2312-0967. Фармацевтичний часопис. 2015. № 2 
Фармацевтична технологія, біофармація, гомеопатія

Pharmaceutical technology, biopharmacy, homeopathy

Table 1. Indicators of efficiency of separate fermentation ( $M \pm m, n=5)$

\begin{tabular}{|c|c|c|c|c|c|c|c|c|c|c|}
\hline \multirow{4}{*}{$\begin{array}{l}\text { Indicators of } \\
\text { efficiency of } \\
\text { fermentation }\end{array}$} & \multicolumn{9}{|c|}{$\begin{array}{l}\text { The total amount of the fermentation starter } \\
\text { (\% of the raw material) }\end{array}$} & \multirow[t]{2}{*}{ Control $^{1}$} \\
\hline & \multicolumn{3}{|c|}{$10 \%$} & \multicolumn{3}{|c|}{$20 \%$} & \multicolumn{3}{|c|}{$30 \%$} & \\
\hline & \multicolumn{10}{|c|}{ Proportion of lactic acid and the yeast flora in the fermentation starter } \\
\hline & 1:1 & $1: 2$ & $2: 1$ & $1: 1$ & $1: 2$ & $2: 1$ & $1: 1$ & $1: 2$ & $2: 1$ & \\
\hline $\begin{array}{l}\text { Number of yeast } \\
\text { cells }{ }^{2}, \mathrm{CFU} / \mathrm{ml} \\
\left(\times 10^{5}\right)\end{array}$ & $\begin{array}{c}9.0 \pm \\
0.4\end{array}$ & $\begin{array}{l}9.7 \pm \\
0.2\end{array}$ & $\begin{array}{l}8.8 \pm \\
0.2\end{array}$ & $\begin{array}{c}9.0 \pm \\
0.2\end{array}$ & $\begin{array}{c}9.8 \pm \\
0.1\end{array}$ & $\begin{array}{c}11.0 \pm \\
0.2\end{array}$ & $\begin{array}{l}8.6 \pm \\
0.3\end{array}$ & $\begin{array}{l}8.8 \pm \\
0.4\end{array}$ & $\begin{array}{l}8.9 \pm \\
0.3\end{array}$ & $\frac{(5.2 \pm 0.3) \times}{10^{3}}$ \\
\hline 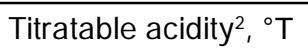 & $65 \pm 1$ & $63 \pm 1$ & $68 \pm 1$ & $70 \pm 3$ & $76 \pm 2$ & $78 \pm 1$ & $66 \pm 2$ & $62 \pm 2$ & $67 \pm 2$ & $45 \pm 1$ \\
\hline
\end{tabular}

Notes: ${ }^{1}$ - indicators of the initial starter;

${ }^{2}$ - the maximum values in $13 \mathrm{~h}$ of fermentation.

Table 2. Indicators of efficiency of joint fermentation $(M \pm m, n=5)$

\begin{tabular}{|c|c|c|c|c|c|c|c|c|c|c|}
\hline \multirow{4}{*}{$\begin{array}{l}\text { Indicators of } \\
\text { efficiency of } \\
\text { fermentation }\end{array}$} & \multicolumn{9}{|c|}{$\begin{array}{l}\text { The total amount of the fermentation starter } \\
\text { (\%of the raw material) }\end{array}$} & \multirow[t]{2}{*}{ Control $^{1}$} \\
\hline & \multicolumn{3}{|c|}{$10 \%$} & \multicolumn{3}{|c|}{$20 \%$} & \multicolumn{3}{|c|}{$30 \%$} & \\
\hline & \multicolumn{10}{|c|}{ Proportion of lactic acid and the yeast flora in the fermentation starter } \\
\hline & $1: 1$ & $1: 2$ & $2: 1$ & $1: 1$ & $1: 2$ & $2: 1$ & $1: 1$ & $1: 2$ & $2: 1$ & \\
\hline $\begin{array}{l}\text { Number of yeast } \\
\text { cells }{ }^{2}, \text { CFU/ml } \\
\left(\times 10^{4}\right)\end{array}$ & $\begin{array}{c}8.8 \pm \\
0.2\end{array}$ & $\begin{array}{c}8.8 \pm \\
0.5\end{array}$ & $\begin{array}{c}9.1 \pm \\
0.2\end{array}$ & $\begin{array}{c}9.0 \pm \\
0.4\end{array}$ & $\begin{array}{c}8.7 \pm \\
0.1\end{array}$ & $\begin{array}{c}9.2 \pm \\
0.1\end{array}$ & $\begin{array}{l}7.9 \pm \\
0.4\end{array}$ & $\begin{array}{l}8.3 \pm \\
0.2\end{array}$ & $\begin{array}{l}8.2 \pm \\
0.2\end{array}$ & $\frac{(5.2 \pm 0.4) \times}{10^{3}}$ \\
\hline 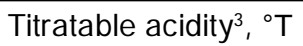 & $73 \pm 2$ & $72 \pm 2$ & $74 \pm 1$ & $73 \pm 2$ & $73 \pm 4$ & $74 \pm 2$ & $73 \pm 1$ & $72 \pm 1$ & $73 \pm 3$ & $40 \pm 3$ \\
\hline
\end{tabular}

Notes: ${ }^{1}$ - indicators of the initial starter;

2 - the maximum values within all $72 \mathrm{~h}$ of the research (the maximum value was achieved in $48 \mathrm{~h}$, then the number of cells was decreased, and it was less than in control in $72 \mathrm{~h}$ );

${ }^{3}$ - the maximum values within all $72 \mathrm{~h}$ of the research (it was achieved only in $70 \mathrm{~h}$ ).

showed that indicators of efficiency of fermentation were the highest for the amount of the starter of $20 \%$ and proportion of the flora in the starter - 2:1 for both methods of fermentation, but the number of yeast cells for the separate fermentation is higher than for the joint fermentation. Considering the above and the fact that the time of the separate fermentation is (13-14) $\mathrm{h}$ and it is less than for the joint fermentation (70-72) h, it can be argued that the first method is more effective, at least for the koumiss prepararion in the laboratory conditions. And the amount of the fermentation starter of $20 \%$ and the proportion of lactic acid and the yeast flora in the starter of 2:1 are the most effective parameters.

Next stages of the traditional koumiss manufacture technology are cooling, maturation, packaging and storage. So, after fermentation the product was cooled to the temperature of $(16-18){ }^{\circ} \mathrm{C}$ and left on the maturation period of 2-2.5 $\mathrm{h}$ for activation of alcoholic fermentation. Then koumiss was poured into the bottles, hermetically sealed. The ripened product in the bottle was placed in a cooling chamber. The shelf life of the product is 7 days at a temperature of (2-4) ${ }^{\circ} \mathrm{C}$.

Thus, the technology for laboratory preparing koumiss has been developed on the basis of the analysis and laboratory studies conducted.
Since the therapeutic and prophylactic effect of FMP mainly depends on their qualitative and quantitative composition [4], the next step of the studies was to estimate of these parameters and compare with the control - a commercially available product (koumiss LLC "NEO Product").

The results of the studies for determining of the qualitative composition by the Gram's method have shown the presence of gram-positive lactic acid bacilli and streptococci and large oval yeast cells, i.e. certain species of microorganisms, which are characteristic for the microflora of koumiss.

The comparative analysis of the quantitative composition at the beginning and end of the shelf life of the product proposed and the commercially available product is presented in Table 3.

According to the common criteria, the content of lactic acid bacteria in koumiss at the end of the shelf life should be not less than $10^{7}$ cells in $1 \mathrm{ml}$ of the product, the content of yeast - not less than $10^{4}$ cells in $1 \mathrm{ml}$ $[4,13]$. As seen in Table 3, the norm was observed for both products, but the number of cells for the commercial product was at a critical level at the end of the shelf life, and the number of cells for the product proposed was almost the same as at the beginning of the shelf

ISSN 2312-0967. Pharmaceutical review. 2015. № 2 
Фармацевтична технологія, біофармація, гомеопатія Pharmaceutical technology, biopharmacy, homeopathy

Table 3. Determination of the quantitative composition $(M \pm m, n=5)$

\begin{tabular}{|c|c|c|c|c|}
\hline \multirow{2}{*}{$\begin{array}{c}\text { The test samples of } \\
\text { koumiss }\end{array}$} & \multicolumn{2}{|c|}{$\begin{array}{c}\text { The number of cells at the beginning of the } \\
\text { shelf life, CFU/ml }\end{array}$} & \multicolumn{2}{|c|}{$\begin{array}{r}\text { The number of cells at the end of the shelf } \\
\text { life, CFU/ml }\end{array}$} \\
\cline { 2 - 5 } & Lactic acid bacteria & Yeast & Lactic acid bacteria & Yeast \\
\hline The product proposed & $(9.2 \pm 0.3) \times 10^{8}$ & $(2.3 \pm 0.1) \times 10^{6}$ & $(8.5 \pm 0.4) \times 10^{8}$ & $(1.2 \pm 0.2) \times 10^{6}$ \\
\hline $\begin{array}{c}\text { The commercial } \\
\text { product (koumiss LLC } \\
\text { "NEO Product") }\end{array}$ & $(8.5 \pm 0.2) \times 10^{8}$ & $(1.5 \pm 0.1) \times 10^{5}$ & $(2.1 \pm 0.1) \times 10^{7}$ & $(3.9 \pm 0.2) \times 10^{4}$ \\
\hline
\end{tabular}

life. Therefore, the product proposed showed the best quantitative indicator.

Conclusions. 1. The analysis and studies conducted made it possible to choose the optimum ingredients (pasteurized skimmed cow milk, powdered skimmed milk, honey, dry yeast (alcohol flora) and ready biokefir (lactic acid flora), drinking water) and their optimum proportion in the composition of the product proposed (the amount of the fermentation starter is $20 \%$, the proportion of lactic acid and yeast flora in the starter is 2:1).

\section{References}

1. Нутриціологія : навч. посібник [для студ. вищ. навч. закл.] / [Дуденко Н. В., Павлоцька Л. Ф., Цихановська І. В. та ін.] ; під заг. ред. Н. В. Дуденко. - Х. : Світ Книг, 2013. - 560 c.

2. Functional Foods / European Commission. - Luxembourg: Publications Office of the European Union, 2010. - 24 p.

3. Functional aspects of dairy foods in human health: An overview / S. K. Bharti, N. K. Sharma, K. Murari [et al] // Critical review in pharmaceutical sciences. - 2012. - № 1. - P. 35-42.

4. Park Y. W. Bioactive components in milk and dairy products / Y. W. Park. - Singapore : A John Wiley \& Sons, Ltd., Publication, 2009. - 426 p.

5. Производство молока и молочных продуктов в Украине за 12 месяцев 2012 года : аналитический обзор // Молокопереробка. - 2013. - № 2 (89). - С. 22-33.

6. Готовимдомакисломолочныепродукты-Энциклопедия здорового питания. [Електронний ресурс].- Режим доступу : http://kulinar-dream.ru/zdorovoe-pitanie/gotovimdoma-kislomolochnie-produkti.html.

7. Кефир: польза, состав, приготовление в домашних условиях. [Електронний ресурс].- Режим доступу :
2. The rational method of fermentation (separate fermentation), which is the main stage in the process of koumiss preparation, has been chosen; all other stages have been analyzed and performed. Testing of the technology of koumiss developed for home use has been carried out in the laboratory conditions.

3. The research conducted has demonstrated high indicators of the qualitative and quantitative composition providing the therapeutic effect of koumiss; and it allows recommending the technology of koumiss developed for studying under conditions of industrial production.

http://volshebnaya-eda.ru/product/milk/kefir-polza-sostavprigotovlenie-v-domashnix-usloviyax/

8. Бактериальные закваски, отзывы, вопросы. [Електронний ресурс]. - Режим доступу : http://kinder. sumy.ua/forum/index.php?topic $=94110.40$.

9. Максютов Р. Р. Разработка технологии и товароведная оценка йодобогащённых кумысных напитков с инулином : дис. ... кандидата техн. наук : 05.18.15 / Максютов Руслан Ринатович. - Москва, 2014. - 136 с.

10. Молоко и молочные продукты. Титриметрические методыопределениякислотности. Межгосударственный стандарт : ГОСТ 3624-92. - М. : ИПК Издательство стандартов. - 2004. - 8 с.

11. Віннікова О. І. Практикум з мікробіології : методичні рекомендації / Віннікова О. І., Моргуль І. М. - 2-ге вид., доповнене. - Х. : ХНУ імені В. Н. Каразіна, 2009. - 33 с. 12. Шлегель Г. Общая микробиология / Г. Шлегель. - М. : Мир, 1987. - 567 с.

13. Technology development of kumis functional drink / R. Maksyutov, E. Solovieva, A. Mamtsev [et al.] // Ukrainian Journal of Food Science. - 2013. Vol. 1, № 2. - P. 175180.

\section{РОЗРОБКА ЛАБОРАТОРНОЇ ТЕХНОЛОГІЇ ФУНКЦІОНАЛЬНОГО ПРОДУКТУ ХАРЧУВАННЯ КУМИСУ}

\section{О. С. Калюжна}

\section{Національний фрармацевтичний університет, Харків}

Резюме: на основі даних експериментальних досліджень і проведеного аналізу підібраний склад (а саме, пастеризоване знежирене коров'яче молоко, сухе знежирене молоко, мед, сухі дріжджі (спиртова фрлора), готовий біокефір (молочнокисла фрлора), питна вода) і розроблена лабораторна технологія приготування кумису,

ISSN 2312-0967. Фармацевтичний часопис. 2015. № 2 
Фармацевтична технологія, біофармація, гомеопатія

Pharmaceutical technology, biopharmacy, homeopathy

що є фрункціональним продуктом харчування. Були обрані раціональний метод ферментації (а саме, роздільна фрерментація), яка є однією з головних стадій процесу приготування кумису, кількість закваски (20 \%) і співвідношення молочнокислої і дріжджовий фрлори в заквасці (2:1).

Ключові слова: кумис, функціональні продукти харчування, технологія виготовлення.

\section{РАЗРАБОТКА ЛАБОРАТОРНОЙ ТЕХНОЛОГИИ ФУНКЦИОНАЛЬНОГО ПРОДУКТА ПИТАНИЯ КУМЫСА}

\section{О. С. Калюжная}

Национальный фрармацевтический университет, Харьков

Резюме: на основе данных экспериментальных исследований и проведенного анализа подобран состав (а именно, пастеризованное обезжиренное коровье молоко, сухое обезжиренное молоко, мед, сухие дрожжи (спиртовая фрлора), готовый биокесир (молочнокислая фрлора), питьевая вода) и разработана лабораторная технология приготовления кумыса, являющегося функциональным продуктом питания. Были выбраны рациональный метод ферментации (а именно, раздельная фрерментация), которая является одним из главных стадий процесса приготовления кумыса, количество закваски (20 \%) и соотношение молочнокислой и дрожжевой фрлоры в закваске (2:1).

Ключевые слова: кумыс, функциональные продукты питания, технология приготовления.

Отримано 17.03.2015

ISSN 2312-0967. Pharmaceutical review. 2015. № 2 